\title{
Exposure as Collected Pharmaceutical Strength Units
}

National Cancer Institute

\section{Source}

National Cancer Institute. Exposure as Collected Pharmaceutical Strength Units. NCI

Thesaurus. Code C117494.

The unit of measure for the content of an active ing redient in the exposure, expressed quantitatively per dosage unit. 